\title{
Correction to: Recycling of Labada (Rumex) biowaste as a value-added biosorbent for rhodamine B (Rd-B) wastewater treatment: biosorption study with experimental design optimisation
}

\author{
Zeynep Mine Şenol ${ }^{1} \cdot$ Serap Çetinkaya ${ }^{2} \cdot$ Hasan Arslanoglu ${ }^{3}$
}

Published online: 4 February 2022

○ The Author(s), under exclusive licence to Springer-Verlag GmbH Germany, part of Springer Nature 2022

\section{Correction to: Biomass Conversion and Biorefinery}

https://doi.org/10.1007/s13399-022-02324-4

During the production process, the author name Serap Çetinkaya was incorrectly written as Serap Çentinkaya.

The original article has been corrected.

Publisher's note Springer Nature remains neutral with regard to jurisdictional claims in published maps and institutional affiliations.

The original article can be found online at https://doi.org/10.1007/ s13399-022-02324-4.

Hasan Arslanoglu

hasan.arslanoglu@comu.edu.tr

Zeynep Mine Şenol

msenol@cumhuriyet.edu.tr

Serap Çetinkaya

secetinkaya@cumhuriyet.edu.tr

1 Zara Vocational School, Department of Food Technology,

Cumhuriyet University, Sivas, Turkey

2 Department of Molecular Biology and Genetics, Faculty of Science, Cumhuriyet University, Sivas, Turkey

3 Faculty of Engineering, Department of Chemical

Engineering, Çanakkale Onsekiz Mart University, Çanakkale,

Turkey 